\title{
CEO Duality and Financial Performance: Testing the Moderating Role of Firm Age: Evidence from a Developing Economy
}

\author{
Akisimire Richard*, Ernest Abaho, Maureen Tweyongyere \\ Makerere University Business School, Uganda \\ *rakisimire@mubs.ac.ug
}

\begin{abstract}
This paper tests the moderating role of firm age on the relationship between Chief Executive Officer (CEO) duality and financial performance among manufacturing firms in Uganda. A cross section survey was adopted using 78 manufacturing firms in Uganda. Data was analyzed using descriptive statistics, correlation and hierarchical regression. Modgraph software was also used to ascertain the validity of the set hypothesis. Results reveal that whether the CEO doubles as chairman of board or not, this does not significantly affect firm Financial Performance. However, as the firms grow older, the role of CEO-Board Chairman duality phenomenon gains significance in determining financial performance. Therefore, as firms grow in age, the CEOs should not be the same as Board chairpersons if firms have to perform well financially. Since only a single research methodological approach was employed in this study, future research can undertake to use a mixed methods approach to provide more detailed insights. Further, a longitudinal approach can also be employed to study financial performance trends among manufacturing firms over years. Entrepreneurs of these firms should put emphasis on proper segregation of the CEO role and those of the board chairman especially as firms grow in age. A moderating role of firm age on the relationship between CEO duality and financial performance was tested among manufacturing firms; previous studies have tended to test the direct or mediating effects.
\end{abstract}

Keywords: CEO duality, Firm age, financial performance, Manufacturing firms, Uganda.

\section{Introduction}

In this study, we mainly investigate the moderating role of firm age on the relationship between CEO duality and financial performance among manufacturing firms in a developing economy perspective. Most Manufacturing firms in sub-Saharan Africa provide a fulcrum around which their host economies turn (Kamukama, Kyomuhangi, Akisimire, \& Orobia , 2017; Mutambi, 2011; Tumwine et al., 2015). In Uganda for instance, the industrial manufacturing sector is one of the economic pillars of the economy with a GDP contribution of $20 \%$, generating over $80 \%$ of manufactured output (UNIDO, 2013; UBOS, 2017). Comparing the level of economic performance with the government efforts in developing industrialization, this sector should be performing better. Thus, for the economy to prosper there is need to put emphasis on this sector because; in addition to its GDP contribution, the sector creates employment for both the skilled and unskilled labor as well as providing value addition to the agricultural output for both local consumption and export purposes (Nalukenge et al., 2018; Tumwine et al., 2015). Despite their great importance, most manufacturing firms have had challenges of poor financial performance and this sometimes leads to firm failure (Mutambi, 2011; Nkundabanyanga, 2016; Akisimire et al., 2016).

In fact, most of these firms have registered a low return on investment, low return on assets and some of them fail to maintain their liquidity levels (Akisimire et al., 2016; Ishengoma \& Kappel, 2008). Numerous reasons have been observed to cause this poor financial performance. Studies indicate the most of the firms have challenges of owner managers that serve both as CEOs and board chairpersons simultaneously. Subsequently, this impairs the independence of board members while executing their board duties (Hofmann \& Lampe, 2013; Mutambi, 2011). Conspicuously, the board is customarily tasked with an oversight role of evaluating the management team and CEO (Firth et al., 2014; Cornforth, 2004; Freeman, 2008). Because of this, board chairpersons are expected to understand their leadership roles in relation to how it contributes to the performance of the firm (Desoky, \& Mousa, 2013; Kakabadse \& Kakabadse, 2013). Likewise, the CEO is tasked with overseeing the daily operations of the business as well as operationalising strategic plans (Bathula, 2008). This means that, allowing the CEO to double as the board chairman may cause CEOs to perform no duty other than evaluating themselves and the board ends up as a mere rubber stump (Tonello, 2011). Besides, founder CEOs are observed to have a tendency of treating the organization as their "baby" and want to control it as much as possible courtesy of their unified leadership. 
Something that may hinder firm performance in the long run (Mori, Randøy \& Golesorkhi, 2011). Notably, the positions of board chairman and CEO command a lot of power and responsibility. Besides, the effectiveness of the board and management is largely dependent on the efficacy of the CEO and the board chairman respectively (Bathula, 2008). Regulating the power of management and the board affects strategic decisions such as financing (Munir, \& Li, 2018). Thus, serving dual roles has certainly been cited in most debates as paramount in predicting the financial performance of most companies. While well constituted boards are important for successful financial performance (Bathula, 2008; Nkundabanyanga, 2016), there is scanty literature about what constitutes an effective board and how the CEO duality scenario on the board fosters good financial performance of a firm. Extant empirical studies have produced conflicting results (Bathula, 2008; Adams et al., 2005; Ugwoke et al., 2013; Moscu, 2013) and none of the studies have tested the moderating role of firm age on the study variables. Besides, most studies have been conducted in a developed economy perspective, leaving other private sector manufacturing firms in developing economies unstudied. More so, theories and models that have attempted to explain financial performance as predicted by CEO duality have proved to be inadequate in explaining the phenomenon in the private sector firms especially those in a developing economy perspective (Freeman, 2008).

And yet, CEO duality is arguably seen as an important board control mechanism in mitigating agency conflicts, where owner managers have a tendency of performing a dual roles with the aim of managing succession and negotiations (Bathula, 2008; Munir, \& Li, 2018). As a result, poor financial performance among manufacturing firms remains unexplained, something that creates an empirical and theoretical gap. Because of the unique challenges that exist in the turbulent business environment especially in the private sector (UNIDO, 2013). This paper focuses on testing the moderating role of firm age on the relationship between CEO duality and financial performance among private sector manufacturing firms in Uganda. This is because board dynamics are attributed to the firm age differences, in that; the complexities within these firms tend to increase as firms grow, resulting into variations in performance (Aktas et al., 2018; Bathula, 2008). Our findings are expected to contribute to the scholarly debate about the governance structures from the private sector strategic leadership view point using evidence from Uganda. Manufacturing firms in Uganda can use the findings to improve their boards by addressing challenges of CEO duality as a tool to foster firm financial performance, especially as these firms grow in age. The rest of the paper organized as follows: the next section presents literature review and hypotheses. This is followed by the research methodology, the study results, discussion and the final section covers the conclusion and implications derived from the study.

\section{Literature Review}

\section{Theoretical Establishment of this Study}

The Upper Echelons Theory: The central assumption of the Upper Echelons theory is that organizations are a reflection of their top executives and that top executives view their opportunities, threats, alternatives and likelihoods of various outcomes through their own perspective (Hambrick \& Mason, 1984; Tacheva, 2007). The theory attributes the performance outcome of the firm to the characteristics of top management teams and associates (Cannella \& Holcomb, 2005). As a result, the theory offers a new notion into strategic leadership, governance and decision making as well as processes involved in the operations of the firms. According to the theory, it is assumed that if one must understand a good strategy, they must understand strategists (Hambrick \& Mason, 1984). This means that; if the upper level cadres are goods strategist, they would ultimately be in position to make good strategies for the company and vice versa.

Therefore, to effectively execute the oversight functions, the boards are left with the task of understanding the managerial cognitive behavior within the firms they govern so as to create proper synergies with management at an informed point of view other than having mixed ideas. This can be best achieved in situations where the CEO serves a dual purpose of chairing the board (Rechner \& Dalton, 1991). Even in the existence of the diverse board, most of the decisions made in most private sector firms are aligned to the interest and perceptions of the owner managers (Dual CEOs). However, based on the assumptions of the theory that organizations are a reflection of their top managers (Cannella \& Holcomb, 2005; Hambrick \& Mason, 1984), most of its processes and perspectives proposed have not been put to systematic and comprehensive test. Further, the theory still lacks diversity in terms of contextual evidence. 
Managerial Hegemony Theory: In performing its oversight function, the board is entitled to rely on the advice, reports and opinions of management (Huse, 2005). This theory assumes that managers have more powers than the rest of the stakeholders (Munir, \& Li, 2018) because they have a closer interaction with the operations of the business and have the professional knowledge to foster good financial performance (Mace, 1971). Although this theory was developed with respect to large business corporations (Cornforth, 2004), many of the processes it describes are also relevant to small but growing firms. From this perspective, the board especially one that is managed by the CEO ends up embracing management's decisions with no fundamental input and because managers are assumed to know the operational details of the day to day management of the firm (Huse, 2005; Kakabadse et al., 2013), the board therefore decides to embrace or ratify whatever decisions that are taken by management and ends up being mere rubber stamp. Stiles and Taylor (2001) in their research on private sector boards also argue that in situations of CEO duality, board members are unable to constrain managerial opportunism.

By establishing control mechanisms to keep a focus on organizational goals like financial performance. What this informs the current study is that even in the presence of the board, there is a high likelihood of management dominance in strategic decision making. Therefore, unless the board is composed of independent members that are knowledgeable and strong, management under the leadership of a dual CEO may take advantage of the weaknesses to satisfy their own interests. However, one key limitation of the Managerial Hegemony theory is that it undermines the role of the board and considers it as playing a passive role in the strategic direction of the firm (Nkundabanyanga et al., 2015). The theory does not specify the board-management power as well as power boundaries between boards and management (Cornforth, 2004). The theory also puts more focus on management dominance and falls short of specificity in addressing how resourceful the board is in fostering financial performance. That is why in this study, we combine the premises of the Upper Echelons and Managerial Hegemony theories to help complement each other in understanding the roles and limitations of CEO duality.

Contextualising Financial Performance: The financial performance is a general measure of an organization financial health. It is has for overtime been measured differently, But for this study, we focused on capital growth, asset base, return on assets (ROA), return on investments(ROI) profit after tax (PAT) and firm revenues as measures of financial performance. (Hofmann \& Lampe, 2013; Bathula, 2008; Tumwine et al., 2015). For instance, Return on investment is a particular metric used to measure the firms profitability, it specifically measure the amount of returns on a particular investment in relation to the initial investment costs (Mutambi, 2011; Nkundabanyanga, 2016). Mutambi (2011) further explains the key performance indicators among manufacturing firms in terms of plant and machinery, output and other capital investments. In the manufacturing perspective, scholars like Mutambi (2011) argue that key performance indicators (KPIs) among manufacturing firms especially in the recent trend need to be understood mainly because a new paradigm of performance has been adopted by most firms in the industry, given the new technological advancement. On the contrary, Nkundabanyanga (2016) while analyzing the perceived performance among the Ugandan service firms concluded that good financial performance indicators include; equity returns, controlled expenditure and profitable investments as well as shareholders in terms of dividends received.

CEO - Chairman Duality in the Context of Financial Performance: The role of the CEO and that of the board chairman are often intermingled thus creating the scenario of "CEO-chairman duality" (Bathula, 2008). CEO duality holds that these roles are held simultaneously by one party as opposed to independent structures where different persons are meant to serve these roles (Freeman, 2008; Brown, 2008). If maintaining control is imperative for founders, it is likely that the founder CEOs would serve concurrently as board chairpersons. Found out that separating the CEO and board chair positions does not, on its own, improve firm financial performance. However, Tonello (2011) argues that the CEO duality threatens board member independence and accelerates conflict of interest as well as lowering firm value (Aktaset al., 2018) although Munir and Li, (2018) found out that CEOs that are more powerful are less self-centered and tend to make decisions that favor financial strengthening of their firms. In fact Mobbs (2015) argues that CEOs who double as board chairmen are important in strengthening the human capital of a firm and usually have higher firm valuation. However, separation of CEO from the board chairmanship does not necessarily guarantee good performance (Tonello, 2011). It is therefore hypothesized that; H1: There is a significant relationship between CEO duality and financial performance. 
Moderating Role of Firm Age on the Relationship between on CEO Duality and Financial Performance: It is observed that there has been extant research about the relationship between CEO duality and firms' financial performance. However, most of these studies have focused on the direct relationship and not considered contextual factors (Peng, Li, Xie \& Zhongfeng, 2010). The adoption of CEO duality structure represents the exercise of power by the CEO (Bathula, 2008). However, it has been noted that holding multiple titles tends to be a sign of power accumulation and power hoarding (Düztas, 2008; 60). Age is a key antecedent of board structure and firm performance (Coad, Holm, Krafft \& Quatraro, 2018). Firm age is measured by the number of years from the time the firm was incorporated and that firm age has been linked to many decisions of the firm (Bathula, 2008; Brown, 2008. Düztas, (2008) stresses that firms go through a financial growth and their capital structures vary with the age. Thus, as firms grow, board composition also changes in response to the increasing needs.

However, the magnitude of these relationships may differ. For example, founder members that start by serving both roles (CEO/Board chairman) may with time surrender one especially as the firm grows in age (Munir, \& Li, 2018). This may reflect a trade-off between specific benefits of monitoring and costs of such monitoring (Freeman, 2008). Relatively younger firms are expected to earn less in terms of revenue turnover and overall profitability than older ones (Bathula, 2008; Baisi, 2008). This is because they are under the leadership of dual CEOs with less experience in the market and spend a lot of excess funds (Aktas et al., 2018) in market penetration programmes so as to build a sustainable market position (Boone et al., 2007; Bathula, 2008). As a result, they normally have a high costs structure and low return on investment, something that may hamper the overall financial performance of the firm. Further, Boone et al. (2007) also suggest that complexity in board composition in terms of CEO duality increases with firm age as well as financial performance. It is thus hypothesized that; H2: Firm age has a significant moderating effect on the relationship between the CEO duality and financial performance.

\section{Methodology}

Our study adopted a cross-sectional survey approach because the specific and observable fact in question was studied at a particular period in time. We also considered a population of 146 manufacturing firms, which had boards and at the same time registered under their umbrella body; the Uganda Manufacturers Association. Using the Krejcie and Morgan (1970)'s table of sample size determination, a sample size of only 108 firms were considered for this study and these were chosen using the MS Excel random selector. Data was collected using self-administered questionnaire, while financial performance was ascertained by way of reviewing hard data from these firms. However, out of the 108 firms that were studied, only 78 firms responded, making a response rate of 72 percent. We distributed five copies of the questionnaire to the board chairman, and four other board members. Out of which, we considered an average of three per firm for analysis purposes.

\section{Sample Characteristics}

Table 1: Descriptive Statistics - Respondents' Demographics

\begin{tabular}{lrr}
\hline Variables & Frequency & Percentage (\%) \\
\hline Education levels & & 12 \\
Uganda Advanced Certificate of Education & 29 & 8 \\
Diploma & 19 & 43 \\
Degree & 102 & 23 \\
Masters & 54 & 13 \\
Ph.D & 31 & 100 \\
Total & 235 & \\
Age groups & & 3 \\
26-33 & 6 & 22 \\
$34-41$ & 51 & 20 \\
$42-49$ & 48 & 36 \\
$50-57$ & 85 & 19 \\
$58+$ & 45 & \\
\hline
\end{tabular}




\begin{tabular}{lrr} 
& $\begin{array}{c}\text { Journal of Economics and Behavioral Studies (ISSN: 2220-6140) } \\
\text { Vol. 12, No. 3, pp. 53-64, June 2020 }\end{array}$ \\
\hline \hline Total & 235 & 100 \\
Marital status & 29 & 12 \\
Single & 201 & 86 \\
Married & 5 & 2 \\
Divorced & 235 & 100 \\
Total & & \\
Gender & 162 & 69 \\
Male & 73 & 31 \\
Female & 235 & 100 \\
Total & 75 \\
\hline
\end{tabular}

Results in table 1 indicate that, the mainstream of most boards that were studied composed of board members with a bachelor's degree as their highest education level (43\%); were in the age group of 50-57 $(36 \%)$; were married (86\%) and were males (69\%). Results regarding the nature of boards are presented in Table 2 below.

Table 2: Nature of Boards in the Sample

\begin{tabular}{llll}
\hline & & Frequency & Percent \\
\hline Number of directors on the board & $3-6$ & 14 & 17.9 \\
& $6-9$ & 59 & 75.6 \\
Total & Over 9 & 5 & 6.4 \\
Number of female directors do you have on the board & Less than 2 & 78 & 100.0 \\
& $2-5$ & 7 & 1.3 \\
Total & $5-10$ & 2 & 96.2 \\
Number of male directors do you have on the board & & 78 & 2.6 \\
& $2-5$ & 60 & 700.0 \\
Total & $5-10$ & 18 & 23.1 \\
Gender of the board chairperson & & 78 & 100.0 \\
& Male & 72 & 92.3 \\
Total & Female & 6 & 7.7 \\
Is the CEO the same as Board chairman? & & 78 & 100.0 \\
& Yes & 43 & 55.1 \\
Total & No & 35 & 44.9 \\
\hline
\end{tabular}

Most boards had 6-9 directors (42.6\%) while the least number is represented by board members less than 3 $(1.7 \%)$. This would imply that most the boards of manufacturing firms in Uganda are composed of board members who are at the same time directors or owner of the same firms.

Operationalization and Measurement of Variables

\begin{tabular}{|c|c|c|c|}
\hline $\begin{array}{l}\text { Global } \\
\text { Variable }\end{array}$ & Operationalization & Measurement & Sample Questions \\
\hline $\begin{array}{l}\text { Financial } \\
\text { performance }\end{array}$ & $\begin{array}{l}\text { Financial performance was } \\
\text { measured in terms of revenue, } \\
\text { return on assets, return on } \\
\text { equity, return on investment and } \\
\text { profit after tax (Hofmann\& } \\
\text { Lampe, 2013; Bathula, 2008; } \\
\text { Tumwine et al., 2015). }\end{array}$ & 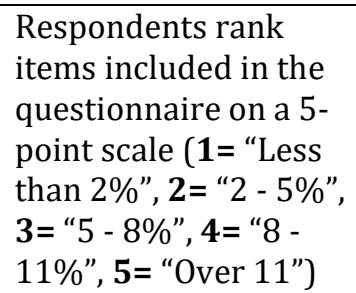 & $\begin{array}{l}\text { Data was captured from the } \\
\text { financial reports of companies. } \\
\text { Sample questions included; } \\
\text { Return on investment has } \\
\text { increased by.... } \\
\text { And return on equity has } \\
\text { increased by.... }\end{array}$ \\
\hline CEO Duality & $\begin{array}{l}\text { CEO duality is arguably seen as } \\
\text { an important board control } \\
\text { mechanism in mitigating agency } \\
\text { conflicts, where owner managers } \\
\text { have a tendency of performing a } \\
\text { dual roles with the aim of }\end{array}$ & $\begin{array}{l}\text { Independent variable } \\
\text { was a categorical } \\
\text { variable and was } \\
\text { measured using a } \\
\text { single question } \\
\text { requiring a response }\end{array}$ & $\begin{array}{l}\text { Respondents were asked } \\
\text { whether the board chairman } \\
\text { doubled as the CEO or not. }\end{array}$ \\
\hline
\end{tabular}


managing succession and negotiations (Bathula, 2008; Munir, \& Li, 2018).

Firm age This captured as moderating variable was captured by considering the number of years the firm has been in existence and this was achieved by referring to the certificates of incorporation. (Peng, Li, Xie \& Zhongfeng, 2010) of either 'yes' or 'no'

Respondents rank items included in the questionnaire on a 5 point scale
Respondents were asked the number of years the firm has been operation and this was confirmed by referring to the certificates of incorporation

Data Analysis: The data collected was screened for outliers and missing values. This was followed by testing the parametric assumptions with an objective of establishing whether to perform parametric tests or nonparametric tests. Descriptive statistics were used to describe the demographic characteristics of the study sample and summarize the data using frequencies, means and standard deviations. Pearson correlation analysis was performed to test the associations between the study variables. In order to test the moderation effects of firm age, a hierarchical regression was conducted to obtain the relationships between CEO Duality, firm age, financial performance and the interaction term. The results were used for a graphical presentation of interaction effects using Jose (2008)'s modgraph software.

\section{Results}

Zero Order Correlation Analysis: A Pearson correlation coefficient (r) analysis was conducted to test the associations between, CEO Chainman Duality and firm financial performance. Results are presented as shown in the table 3 below.

Table 3: Correlation Results

\begin{tabular}{llllllll}
\hline & $\mathbf{1}$ & $\mathbf{2}$ & $\mathbf{3}$ & $\mathbf{4}$ & $\mathbf{5}$ & $\mathbf{6}$ & $\mathbf{7}$ \\
\hline CEO Duality-1 & 1.000 & & & & & & \\
Firm Revenue-2 & -.065 & 1.000 & & & & & \\
Asset Base-3 & -.074 & $.517^{* *}$ & 1.000 & & & \\
Return On Investment-4 & -.036 & $.485^{* *}$ & $.631^{* *}$ & 1.000 & & \\
Return On Assets-5 & -.071 & $.475^{* *}$ & $.379^{* *}$ & $.496^{* *}$ & 1.000 & & \\
Profits After Tax-6 & .120 & $.296^{* *}$ & .136 & $.231^{*}$ & $.433^{* *}$ & 1.000 & \\
Financial Performance-7 & -.031 & $.753^{* *}$ & $.736^{* *}$ & $.767^{* *}$ & $.771^{* *}$ & $.598^{* *}$ & 1.000 \\
**. Correlation is significant at the 0.01 level (2-tailed). & & & & \\
*. Correlation is significant at the 0.05 level (2-tailed). & & & & \\
\hline
\end{tabular}

The results in table 5 show that there is an insignificant relationship between CEO Chairman Duality and overall financial performance $(\mathrm{r}=-.031, p>.05)$ and all indicators of financial performance. This implies that CEO does not have a significant impact on financial performance among the Ugandan manufacturing firms. These findings contradict with those of Bathula (2008) who posits that holding two positions creates a powerful individual and thus makes the board less effective in exercising its governance roles. Given all these powers, the CEO who doubles as the board chairman tends to possess a lot of dominance (Munir \& Li, 2018) and is more likely to undermine the decisions taken by the board (Bathula, 2008). To achieve this, it is observed that the CEO/chairman purposively appoints mainly friend and family members to perform both top management and board duties. Even when such fundamental decisions are taken by the board, implementation of such decisions fall on the deaf ears of the same CEO that already has assumed such supreme powers (Nkundabanyanga et al., 2015; Melyoki, 2005). Accordingly, the study findings provide no support for hypothesis $\mathbf{1}$.

Moderation Effect of Firm Age: The moderating effect of firm age in the relationship between CEO Duality, and financial performance was tested using a hierarchical regression and confirmed using the Modgraph software by Jose (2008). The results are as follows. 
Table 4: Hierarchical Regression Results

\begin{tabular}{llll}
\hline & Model 1 & Model 2 & Model 3 \\
\hline (Constant) & $2.640^{* *}$ & $2.719^{* *}$ & $5.575^{* *}$ \\
CEO Duality & -.048 & -.047 & $.180^{*}$ \\
Firm Age & & -.024 & $-.859^{*}$ \\
Interaction Term & .031 & .042 & $.623^{*}$ \\
R & .001 & .002 & .233 \\
R Square & .485 & .488 & .478 \\
Std. Error of the Estimate & .001 & .001 & .053 \\
R Square Change & .075 & .057 & 4.120 \\
F Change & .786 & .812 & .046 \\
Sig. & & & \\
Dependent Variable: Financial Performance & & & \\
$*$. p<.05 and **.p p .01 & & & \\
\hline
\end{tabular}

The models in table 6 are defined by the following regression equations:

Model 1: $\mathrm{FP}=\mathrm{a}+\mathrm{b} 1 \mathrm{CD}+\mathrm{e}$

Model 2: $\mathrm{FP}=\mathrm{a}+\mathrm{b} 1 \mathrm{CD}+\mathrm{b} 2 \mathrm{FA}+\mathrm{e}$

Model 3: FP $=\mathrm{a}+\mathrm{b} 1 \mathrm{CD}+\mathrm{b} 2 \mathrm{FA}+\mathrm{b} 3 \mathrm{CDFA}+\mathrm{e}$

Where:

FP - Financial performance

$\mathrm{a}$ - is a constant, b1, b2, b3 are - unstandarised coefficient

CD \& FA represent centered values of CEO Duality and Firm age respectively

CDFA represent the interaction term (CEO Duality $\mathrm{x}$ firm age)

Results in models 1 and 2 above, show that there is an insignificant relationship between CEO Duality and financial performance. However, with the introduction of the interaction term (CEO duality x Firm age) in model 3, the results reveal significant inverse relationships between CEO duality and financial performance; while the relationship between the interactive term and financial performance was found to be significant $(\beta$ $=.623, \mathrm{p}<.05$ ). Moreover, the inclusion of the interactive term in model 3 increased the predictive power of the main effects by 5 percent (R Square change $=.053$ ), from 0.1 percent to 5.3 percent. Since the interactive term (CEO duality $\mathrm{x}$ firm age) significantly added an extra variance of 5 percent, it means that the interactive term boosts the explanatory power of the main effects, thereby causing better results than what the main effects would have registered. On the basis of Peng et al. (2010), the result signifies that CEO duality and firm age significantly interact or fuse to cause better financial performance of manufacturing firms. The results provide support for hypothesis H2.However, Jose (2008) argued that the complementary effect of variables can be appropriately confirmed and interpreted basing on the slopes of the graphs. Thus, the means and standard deviations of both main effects (centered variables) as well as the un-standardized regression coefficients (the Bs for the third model) in the Table 6 were used as inputs to ModGraph Program to generate the graph shown in Figure 1.

Figure1: Moderation Effect of Firm Age on the Relationship between CEO Duality and Financial Performance

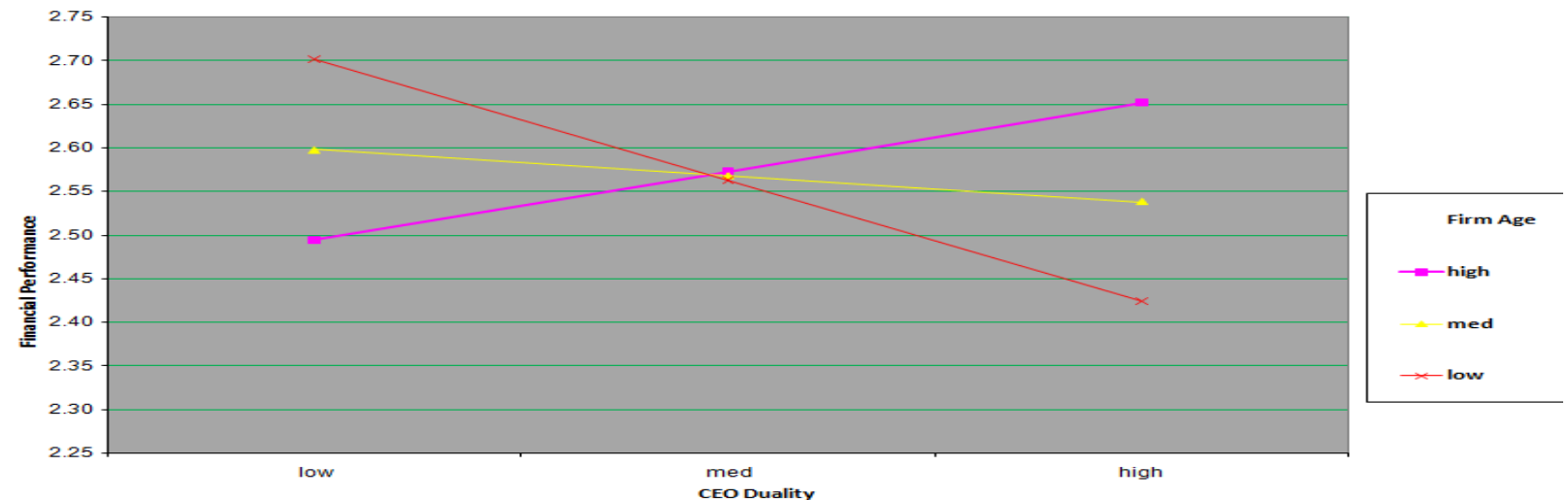


From figure 1 above, simple slopes for the association between distance and satisfaction were tested for low ( -1 SD below the mean), moderate (mean), and high ( +1 SD above the mean) levels of firm age. Each of the simple slope tests revealed a significant negative association between CEO duality and financial performance, but the CEO duality was more strongly related to financial performance with increased levels of firm age.

\section{Discussion}

The debate about CEO duality is not yet definitive because it has not yet exhausted all the contexts both methodologically and philosophically. What we found in this study extends the scholarly buildup of the debate by introducing the manufacturing sector in Uganda. An insignificant but negative relationship between CEO Chairman Duality was observed with financial performance. This means that whether the CEO is the same person chairing the board or not, this has nothing to do with level of financial performance among manufacturing firms. The justification of this is that, unlike in the public sector where CEOs are mere employees doing the agents' role and in most cases act with self-interests, the contextual situation in the private sector is different because most CEO are indeed the owners of the firms and therefore have a special attachment to the success or failure of the firm. Considering the role of firm age in moderating the relationship between CEO duality and financial performance, it is surprising to note that whereas the direct relationship between CEO duality and financial performance was found to be insignificant, the introduction of the interaction term (CEO duality x Firm age) reversed the predictive power and showed significant results. This means that for CEO duality to cause variations in a firm's financial performance, there must a moderating factor, in this case firm age. The findings lend support to those of Mori, Randøy and Golesorkhi (2011) who posit that founder CEOs have a tendency of treating.

The organization as their "baby" and want to hold on to and control it as long as possible. Findings are also consistent with the observations of Bathula (2008) whose contentions are in support of a significant interactive effect of firm age on CEO duality and financial performance. Important to note is that; as these manufacturing firms grow in age and operation increase, they tend evolve overtime and finally get to a point that requires the separation of the two duties for governance controls to prevail. Certainly, this was found to be a common practice among the Ugandan manufacturing firms with 55.1\% of the firms with dual CEOs. Empirically, the initial proprietors of these firms were found to have a tendency of holding the two powerful positions because of the fear to surrender power as well as achieving strong but ambiguous leadership (Nkundabanyanga, 2016). As a result, most firms were found to merely appoint board members just to embrace the adoption of governance practices but when in the actual sense, the oversight function is performed by CEOs. According to our findings, the CEOs were found to perform more of the operational activities by conducting supervisory actions with judicious use of strategies to accomplish certain goals of their interests. Our findings concur with those of Bathula (2008) who posits that holding two positions creates a powerful individual and thus makes the board less effective in exercising its governance roles. Given all these powers, the CEO who doubles as the board chairman tends to possess a lot of hegemony.

Is more likely to undermine the decisions taken by the board as suggested by the managerial hegemony theory (Huse, 2005; Mace, 1971). We equally concur with the arguments of Nkundabanyanga et al. (2015) and Melyoki, (2005) who posit that; when such fundamental decisions are taken by the board. Implementation of such decisions fall on the deaf ears of the same CEO that already has assumed such supreme powers. Similarly, Jensen, (1993) also contends that vesting the board roles under the headship of the CEO that is a member of management would undermine the oversight functions of the board and finally endangers the checks and balances which are essential ingredient of good internal controls. From the managerial hegemony theory perspective, CEO duality is on the contrary seen to carry bad performance consequences since it is assumed to undermine board function (Fama, 1980; Boyd, 1995; Clark, 1984). And because the board of directors is the apex of the decision making or control process of the firm, entrusting the CEO with the board chairman position exemplifies the ultimate conflict of interest (Adams et al., 2005; Bernard, 2012). Ideally, combining the two sensitive roles could have far reaching implications on accountability. This is especially true when the person in charge does not have the organization mission and vision at heart especially where the person serving the dual role is not the original proprietor of the business (Ugwoke et al., 2013). However, our school of thought stands to agree the augments of the upper echelons theory which support CEO duality. 
This ideology lends similar facts like what was found to empirically transpire with in some of the manufacturing, firms in Uganda especially those whose dual role was in the hands of the proprietors. And because both management and the board members were appointed by the same CEO/Chairman, it is reportedly trouble-free to have both parties operating as a one strong team under the headship of a single person. To achieve this, it is observed that the CEO/chairman purposively appoints mainly friend and family members to perform both top management and board duties. Ideally, combining two positions offers a single focal point for the firm leadership because a powerful CEO/board chairman creates an image of stability and instills wellbeing of the employees as well as the shareholders (Bernard, 2012). Interestingly, findings indicate that most of the decisions made in most manufacturing firms in Uganda are aligned to the interest and perceptions of the top managers especially in situations of CEO duality.

At a macroeconomic perspective, the strategies and direction in which firms view governance ideas is highly influenced by the corporate governance systems present in an economy (Nkundabanyanga et al., 2015; UNIDO, 2007). Adding to this, our findings indicate that the introduction and operationalization of the Institute of Corporate Governance in Uganda in 2008 and the resurrections of the Uganda Manufacturers Association have of recent greatly improved the adoption and ideology of effective corporate governance practices among the Ugandan manufacturing firms. This therefore presents a valid justification for the paradigm shift from the historical norms of "micromanagement" within which industrial enterprises were governed to the recent adoption of governance practice. Owing to our findings, it is worth contending that as the firm grows in age, founder CEOs who serve dual roles tend to gain more experience and thus are in a better position to add value to the firm.

\section{Conclusion and Implications}

Owing to our findings and the subsequent discussion above, we thus conclude that; whether firms are managed by dual CEOs or not, it has no significant impact on the performance levels of manufacturing firms in Uganda. Our study makes a deep rooted theoretical contribution by presenting considerable support to the upper echelons theory, with less support to the managerial hegemony theory. We further add to the body of knowledge by testing the moderating role of firm age. The introduction of firm age as a moderating variable reversed the predictive power and showed significant results. This means that, for CEO duality to cause variations in a firm's financial performance, there must a moderating factor; in this case firm age. Perhaps, this is because these firms operate in a private sector setting where most CEOs were found to act with judicious use of means to accomplish certain goals of their interests. Most firms were majorly family owned with owner mangers playing the duo role and most of their boards were composed of members of management. Some boards were found to be formed for formality purposes with most of their processes under the ambiguous leadership of a duo CEO. And yet, a board room is a place where strategic decisions are made, risk overseen and governance issues reviewed. We thus contend that; it is imperative for proprietors to have these boards as independent as possible if independent decisions are to be taken overtime especially as these firms grow and expand.

This would ultimately mitigate challenges of dominance as well as lessen issues of conflict of interest on the board. In fact, this would fundamentally help to manage the succession plan as well as the going concern of the business especially where the "young cadres" are mentored into the system. From the managerial perspective, since the board is at the apex of the decision making or control process of the firm, the current study observed that entrusting the CEO with the board chairman position creates a crisis of "who evaluate who". We thus recommend a considerable segregation of the two duties especially as the firm grows in age and where underperforming CEOs may take advantage of the system and its operation. Once these positions are separated, it is highly probable that the board under the headship of an independent chairman will set key performance indicators for the CEO and his management teams something that may help. To achieve sustainable performance as the firm grows in age and expand overtime. Otherwise, combining the two sensitive roles could have far reaching implications on stewardship accounting especially when the person in charge does not have the organization mission and vision at heart. And because findings indicate that most firms are still in their early stages of development, deliberate efforts as suggested by Melyoki, (2005) must be devised to evolve effective governance practice that fit a developing economy (Uganda) context. Thus, it is reasonable to suggest that; for manufacturing firm in their start up stage. 
CEO duality may not be a paramount prerequisite though a shift may come by as the firm grows in age. This is because of the earlier observation that CEO duality mitigate bureaucratic procedures and escalates the efficiency in the decision making process, something that help the firm to undertake sensitive accomplishment especially at the point of commencement and market penetration. At policy level, it was observed that the introduction and operationalization of the Institute of Corporate Governance. In Uganda in 2008 and the resurrection of the Uganda manufacturers association (UMA) have of recent greatly improved the adoption and ideology of effective corporate governance practices among the Ugandan manufacturing firms. However, there is still need for policy makers through the Ministry of Trade, Industry and Comparatives, UMA, the Institute of Corporate Governance (ICGU) and others to revise practical governance mechanisms that contextually fit in a private sector setting especially the manufacturing firms. The firms in the study were found to operate in a turbulent and dynamic business environment characterized by numerous business challenges. Some of these firms were found to operate with "micromanagement" style especially those under the leadership of dual CEOs.

There is therefore need for the policy makers to create and conduct sensitization programme country wide to have the manufacturing firm owners more aware of the continued adoption to the corporate governance practice especially on how they structure. Their boards under the leadership of independent chairmen especially as these firms grow in age. In fact, as it was earlier put; most firms were found to adopt governance practices to depict a good image when in reality, internal operations are different. There is further need to have these firms aware of the benefit of having good governance mechanisms especially having boards that are well composed with clear and segregated duties, and how this in the end result into sustainable firm financial performance. Conclusively, our study adopted a single methodological research approach that was limited to quantitative approach. Future research could adopt a mixed approach and triangulate data. Our study was also limited to a cross sectional approach, a longitudinal approach could also be adopted to understand the financial performance trends among manufacturing firms in Uganda overtime. Lastly, by virtue of our findings, there are other factors that were not part of this study and therefore may require future consideration.

\section{References}

Adams, R., Almeida, H. \& Ferrera, D. (2005). Powerful CEOs and their impact on corporate performance. Review of Financial Studies, 18(5), 1403-1432.

Akisimire, R., Masoud, M. S., Baisi, M. D. \& Orobia, L. A. (2016). Board Member Age Diversity and Financial Performance of Manufacturing Firms: A Developing Economy Perspective. Journal of Economics and Behavioral Studies, 8(5), 120-132.

Aktas, N., Andreou, P. C., Karasamani, I. \& Philip, D. (2018). CEO Duality, Agency Costs, and Internal Capital Allocation Efficiency. British Journal of Management, Onine.

Baisi, M. D. (2008). The dynamics of SME Financing Decisions and performance in a developing Economy. The Case of Tanzania. Dar es Salaam: University of Dar es salaam, Tanzania.

Bathula, H. (2008). Board Characteristic and firm performance. New Zealand: Auckland University of Technology.

Bernard, I. (2012). Corporate governance in Nigeria, what we need to do'. Investment platform Mutual Alliance Research, 38-39.

Boone, A. L., Field, L. C., Karpoffc, J. M. \& Raheja, C. G. (2007). The determinants of corporate board size and composition: An empirical analysis. Journal of Financial Economics, 85, 66-101.

Boyd, B. (1995). CEO duality and firm performance: a contingency model'. Strategic Management Journal, 16, 301-12.

Brown, R. (2008). Business Ethics. Canadian Business Review, 21(1), 39.

Cannella, A. A. \& Holcomb, T. (2005). A Multi-Level Analysis of the Upper-Echelons Model, Multi-Level Issues in Strategy and Methods. Research in Multi Level Issues, 4, 195 - 237.

Clark, K. (1984). Unionization and firm performance: The impact on profits, growth, and productivity. American Economic Review, 74, 893-919.

Coad, A., Holm, J., Krafft, J. \& Quatraro, F. (2018). Firm age and performance. Journal of Evolutionary Economics, 28(1), 1-11. 
Cornforth, C. (2004). The governance of cooperatives and mutual associations: A Paradox Perspective. Annals of Public and Cooperative Economics, 75(1), 11-32.

Desoky, M. A. \& Mousa, G. A. (2013). The impact of firm characteristics and corporate governance attributes on internet investor relations; Evidence from BahrainInt. Journal of Business and Emerging Markets, $5(2), 19-147$.

Duztas, S. (2008). Corporate Governance: The Effects of Board Characteristics, Information Technology Maturity and Transparency on Company Performance. ed Tepe University. Istanbul: Institute of Social Science.

Fama, E. F. (1980). Agency Problem and the Theory of the Firm. Journal of Political Econom, 88(2), 288-308.

Firth, M., Wong, S. \& Yang, Y. J. (2014). The double-edged sword of CEO/chairperson duality in corporatized state-owned firms: evidence from top management turnover in China. Journal of Management and Governance, 18(1), 207-220.

Freeman, R. (2008). Managing for stakeholders. In T. a. Donaldson, Ethical Issues in Business: A Philosophical Approach, (8), 39-53.

Hambrick, D. C. \& Mason, P. A. (1984). Upper Echelons: The Organisation as a reflection of its top managers. The Academy of Management Review, 9(2), 193-220.

Hofmann, E. \& Lampe, K. (2013). Financial statement analysis of logistics service providers: ways of enhancing performance. International Journal of Physical Distribution \& Logistics Management, 43(4), 321-342.

Huse, M. (2005). Outside Directors in SME Boards: A call for theoretical reflections. Corporate Board: Role, Duties \& Composition, 1(1), 27-37.

Hwai-Shuh, S. (2012). Does Cost Efficiency Lead to Better Financial Performance? A Study on Taiwan International Tourist Hotels. ournal of Hospitality Financial Management, 20(1), 5.

Institute of Corporate Governance, Uganda. (2008). Incorporating Recommended Guidelines for Uganda, the Corporate Governance Manual. Kampala: ICGU.

Ishengoma, E. K. \& Kappel, R. (2008). Business Constraints and Growth Potential of Micro and Small Manufacturing Enterprises in Uganda; Transformation in the Process of Globalisation. Univeristy of Dar es Salaam, Finance. Dar es Salaam: University of Dar es Salaam Business School.

Jensen, M. C. (1993). The modern industrial revolution, exit, and the failure of internal control systems. Journal of Finance, 48(3), 831-880.

Jose, P. E. (2008). ModGraph-I (Version The internet version, Version 2.0.) [Computer software]. . Wellington, New Zealand : Victoria University of Wellington.

Kakabadse, N. K., Kakabadse, A. \& Knyght, R. (2013). CEO/Chairman Role Duality Desire: Resistance to Separation Irrespective of Effect. In A. Kakabadse, \& L. Van den Berghe, How to Make Boards Work. London: Palgrave Macmillan.

Kamukama, N., Kyomuhangi, D. S., Akisimire, R. \& Orobia, L. (2017). Competitive advantage. Mediator of managerial competence and financial performance of commercial banks in Uganda. African Journal of Economic and Management Studies, 8(2), 221-234.

Kasekende, L. \& Opondo, H. (2003). Financing small and medium-scale enterprises (SMEs): Uganda's experience. BOU working paper.

Krejcie, P. \& Morgan, D. W. (1970). Determining sample size for research activities. Educational and Psychological Measurement, 30(3), 7-10.

Likert, R. (1932). A technique for the measurement of attitudes. Archives of Psychology, 140(7), 15-20.

Mace, L. G. (1971). Directors: Myth and Reality. Boston: Harvad Business School Press.

Melyoki, L. L. (2005). Determinants of Effective Corporate Governance in Tanzania. The Netherlands: University of Twente.

Mobbs, S. (2015). Is an Outside Chair Always Better? The Role of Non-CEO Inside Chairs on Corporate Board. Financial Review, 50(4), 547-574.

Mori, N., Randøy, S. \& Golesorkhi, T. (2011). Determinants of Board Structure in Microfinance Institutions: Evidence From East Africa. The Journal of Emerging Market Finance, 12(3), 323-365.

Moscu, R. G. (2013). Does CEO Duality Really Affect Corporate Performance? International Journal of Academic Research in Economics and Management Sciences, 2(1), 156-166.

Munir, Q. \& Li, T. (2018). Nonlinearity between CEO power and firm leverage: evidence from the threshold model. Rev Manag Sci, 12, 593-620. 
Mutambi, J. (2011). Stimulating Industrial Development in Uganda Through Open Innovation.Business Incubators. Blekinge Institute of Technology Licentiate, 10(2), 1650-2140.

Nalukenge, I., Nkundabanyanga, S. K. \& Ntayi, J. M. (2018). Corporate governance, ethics, internal controls and compliance with IFRS. Journal of Financial Reporting and Accounting, 16(4), 764-786.

Nkundabanyanga, S. K. (2016). Board governance, intellectual capital and firm performance. Journal of Economic and Administrative Sciences, 32(1), 20 - 45.

Nkundabanyanga, S. K., Tauringana, V. \& Muhwezi, M. (2015). Governing boards and perceived performance of secondary schools. Preliminary evidence from a developing country. International Journal of Public Sector Management, 28(3), 221-239.

Peng, M., Li, Y., Xie, E. \& Zhongfeng, S. (2010). CEO duality, organizational slack, and firm performance in China. Asia Pacific Journal of Management, 27(4), 611-624.

Rechner, P. \& Dalton, D. R. (1991). CEO duality and organizational performance: A longitudinal analysis. Strategic Management Journal, 12, 155-160.

Stiles, P. \& Taylor, B. (2001). Boards at work: How directors view their roles and responsibilities. Oxford: Oxford University Press.

Tacheva, S. (2007). Top Management Team Diversity: A Multilevel Exploration of Antecedents and Consequences. Rosenberg hill: The University of St. Gallen.

The Uganda Manufacturers Association. (2014). Business Directory. Kampala.

Tonello, M. (2011). Director Compensation and Board Practices Report. USA.

Tumwine, S. A., Kamukama, N. A., Akisimire, R. \& Mutaremwa, G. (2015). A borrowing cost model for effective performance of SMEs in Uganda. World Journal of Entrepreneurship. Management and Sustainable Development, 11(2), 74-89.

Uganda Bearue of Statistics. (2017). Census of Business Establishments. Government of Uganda.

Ugwoke, R. O., Edith, O. \& Obodoekwe, C. N. (2013). Duality role of chief executive officer (ceo) in corporate governance and performance of quoted companies in the Nigerian stock exchange: An appraisal of the perception of managers and accountants. Research Journal of Finance and Accounting, 4(12), 1119.

UNIDO. (2007). Integrated Industrial Policy for Sustainable Industrial Development and Competitiveness. Industrial development: Analysing competitiveness, growth potentials and investment opportunities. Viena: United Nations Industrial Development Organisation.

UNIDO. (2013). The Role of Manufacturing and Structural Change. Kampala: United Nations Industrial Development Organization. 